\title{
Settlement of the gregarious tube worm Hydroides dianthus (Polychaeta: Serpulidae). II. Testing the desperate larva hypothesis
}

\author{
Robert J. Toonen*, Joseph R. Pawlik \\ Department of Biological Sciences, Center for Marine Science Research, University of North Carolina at Wilmington, \\ Wilmington, North Carolina 28403-3297, USA
}

\begin{abstract}
We have documented patterns of gregarious and nongregarious settlement among the larvae of the gregarious tube worm Hydroides dianthus (Verrill, 1873) and shown that larvae do not exhibit decreased substratum-specificity throughout a prolonged planktonic period regardless of prior exposure to experimental substrata. Previous investigations with barnacles and polychaetes have suggested that the colonization of new substrata occurs because larvae become less discriminating as they age, i.e. that they become 'desperate' to settle after searching unsuccessfully for conspecifics for some period of time. This hypothesis, first proposed by Knight-Jones \& Wilson, is based on an energetic model in which non-feeding (lecithotrophic) larvae continue to search for specific substrata as long as their energetic reserves allow, but begin to accept sub-optimal habitat rather than exhaust their reserves and die without metamorphosing. Here, we examined whether it is possible to induce decreased substratum-specificity among competent larvae of the gregarious tube worm $H$. dianthus, which has feeding (planktotrophic) larvae. We show that neither altered feeding regimes nor larval starvation lead to decreased substratum-specificity among competent larvae; although larvae maintained at lower food concentrations take longer to reach competency, the qualitative patterns of settlement on biofilm and conspecifics is unaltered by feeding regime. Furthermore, starving competent larvae results in a loss of competency rather than larval desperation. Larvae belonging to different size classes $(<79,80$ to 99,100 to 126 , and $>127 \mu \mathrm{m})$ showed similar patterns of settlement, and differences among sibling cultures with different mean larval sizes resulted from a decrease in the proportion of larvae settling in response to conspecifics rather than an increase in the proportion settling in response to biofilm. We examined a number of obvious life-history characters for correlations with the tendency for larvae to settle nongregariously, and found that although a variety of life-history traits showed significant correlations, only the total number of eggs spawned by a dam was significantly correlated with the proportion of larvae settling in response to biofilm $\left(r^{2}=0.19\right)$, and the slope of this relationship was negative. These results are again diametric to predictions of the desperate larva hypothesis, and indicate that larval desperation is unlikely to be a general explanation for the initiation of monospecific aggregations of fouling marine invertebrates.
\end{abstract}

KEY WORDS: Colonization · Gregarious settlement $\cdot$ Habitat choice $\cdot$ Hydroides dianthus $\cdot$ Polychaete Resale or republication not permitted without written consent of the publisher

\section{INTRODUCTION}

Considerable research over the past several decades has centered around the settlement patterns of marine invertebrate larvae. This emphasis on settlement has

${ }^{*}$ Present address: Center for Population Biology, Section of Evolution and Ecology, University of California, Davis, California 95616, USA. E-mail: rob@biogeek.ucdavis.edu been due in part to the controversy concerning mechanisms of marine community formation and regulation (e.g. Sutherland \& Karlson 1977, Dean \& Hurd 1980, Raimondi 1988a), but also to the economic importance of many invertebrates, such as oysters (e.g. Cole \& Knight-Jones 1949, Tamburri et al. 1992, Zimmerfaust \& Tamburri 1994), scallops (e.g. Yvin et al. 1985), mussels (e.g. Eyster \& Pechenik 1987), and species that commonly foul man-made structures placed in the sea 
(e.g. Knight-Jones 1953, Raimondi \& Martin 1991). Approximately $80 \%$ of marine organisms (about 90000 described species), both vertebrate and invertebrate, have a biphasic life-cycle and produce planktonic larvae which spend a variable amount of time (ranging from minutes to months) developing in the water column before settling and metamorphosing into the adult life-form (Thorson 1964). This planktonic larval stage is of particular significance to benthic marine invertebrates, many of which are sessile or have highly limited dispersal capabilities as adults. Research on patterns of larval settlement suggest that most larvae settle and metamorphose in response to specific substratum-derived compounds, even if identification of the specific compounds responsible often remains elusive (reviews by Burke 1996 and Pawlik 1992).

The importance of larval settlement patterns, and the effects of variable larval recruitment on community development and structure in marine systems is widely recognized (e.g. Sutherland \& Karlson 1977, Dean \& Hurd 1980, Raimondi 1988b, 1990, Menge 1991, Gaines \& Bertness 1993). Traditionally, larvae have been considered a relatively homogeneous population, each individual searching for a suitable substratum (largely mediated through behavioral responses to the presence of substratum-derived cues) on which to settle and metamorphose; and while variability in larval response appears the rule rather than the exception, studies specifically examining the variability of larval response to specific settlement cues are rare (Raimondi \& Keough 1990). Raimondi \& Keough argued that the larvae of virtually all species studied to date exhibit individual variation, and reviewed the evidence for variable responses of larvae to inductive cues; they lamented the fact that in later summaries of original works all variability in larval responses was typically omitted. They pointed out that this trend to ignore variability in response among larvae indicates an implicit assumption that larval variability, if it exists, is unimportant (Raimondi \& Keough 1990). Like Raimondi \& Keough, we feel that this assumption is unfounded, and argue that individual variability among larvae in their response to substrata is an important consideration in the ecology and evolutionary biology of these species.

We have previously shown that among the larvae of the gregarious tube worm Hydroides dianthus there are some that settle in response to both conspecifics and biofilm, and that gregarious and nongregarious larval settlement occurs regardless of previous exposure of larvae to experimental substrata (Toonen \& Pawlik 1994, 2001a, this issue). Here we extend the results of our previous research to examine specifically whether we can induce the larvae of a gregarious species to settle in a nongregarious manner. Knight-Jones
(1951, 1953) and Wilson (1953) were the first to propose that those larvae unable to locate a suitable substratum become less discriminatory in their settlement over the planktonic lifespan (the 'desperate larva' hypothesis). Although this explanation seems to be widely accepted, we know of little data to test this hypothesis, and our data (Toonen \& Pawlik 1994, 2001a) are diametric to the predictions of the desperate larva hypothesis. For $H$. dianthus, the majority of competent larvae (typically 80 to $100 \%$ ) settled only in response to specific cues associated with live conspecific worms (Toonen \& Pawlik 1996), while a small proportion of competent larvae appear to settle in response to uninhabited biofilmed substrata even after rejecting conspecific inhabited substrata previously (Toonen \& Pawlik 1994, 2001a). Neither group of larvae appeared to show any evidence of decreased substratum-specificity with time, and if anything they became more substratum-specific with time in our experiments (Toonen 1993, Toonen \& Pawlik 1994, 2001a). Based on these results, we argue that aggregations of $H$. dianthus must develop from a 2-step process: first, 'founders' colonize a suitable, but previously uninhabited substratum, then 'aggregators' subsequently settle in response to the presence of living conspecifics on those substrata capable of supporting post-metamorphic survival and growth (Toonen \& Pawlik 1994).

The desperate larva hypothesis as proposed by Knight-Jones $(1951,1953)$ and Wilson (1953), however, is essentially an energetic argument in which larvae search for an appropriate substratum for as long as they are able, but begin to accept suboptimal substrata as their energetic reserves run low and the end of their planktonic lives approach. Jaeckle (1994) confirmed that although the duration of the planktonic lifespan of non-feeding larvae of the bryozoan Bugula neritina can be modulated through uptake of dissolved organics, the maximum planktonic period is determined principally by the energetic content of larvae. The original hypothesis was proposed to explain decreased substratum-specificity in non-feeding (lecithotrophic) larvae, but the planktotrophic larvae of Hydroides dianthus are capable of feeding and delaying metamorphosis for up to 10 times the pre-competent period without obvious consequences to settlement success (Toonen \& Pawlik 1994, 2001a). However, other studies have shown that there are significant settlement and post-settlement consequences to delaying metamorphosis among feeding (planktotrophic) polychaete larvae (e.g. Qian et al. 1990), and even feeding larvae cannot delay settlement indefinitely. Thus, we wanted to examine possible explanations for the nongregarious settlement of larvae of a gregarious species in the hope of addressing the question of how monospecific aggregations are initiated if larvae are strongly gre- 
garious. The most obvious logical analog to depletion of larval energy content (as demonstrated by Jaeckle 1994) determining planktonic duration for feeding larvae would be food limitation after reaching larval competency. Because the desperate larva hypothesis is really an energetic argument, we wanted to test whether energetic constraints rather than absolute planktonic duration per se could account for nongregarious settlement of larvae of the gregarious tube worm $H$. dianthus. If energetic or environmental factors cannot account for the observed patterns of larval settlement, then a more complicated hypothesis for the initiation of aggregations must be postulated. Here, we examine life-history correlates of nongregarious settlement and explore the effects of food limitation on the patterns of gregarious and nongregarious settlement among the larvae of $H$. dianthus.

\section{MATERIALS AND METHODS}

General larval culture and assay techniques. Adult Hydroides dianthus (Verrill, 1873) were collected from large (125000 l) seawater settling tanks at the former Wrightsville Beach desalination plant, or from Banks Channel under the drawbridge access to Wrightsville Beach, North Carolina (where the seawater intake for the settling tanks is located). Aggregations of $H$. dianthus were kept in running, unfiltered seawater drawn from these same settling tanks until spawned.

Adult Hydroides dianthus were spawned and larvae were cultured following the methodology described in Toonen \& Pawlik $(1996,2001$ a) Unless otherwise specified, cultures were maintained at 10 larvae ml-1 in 31 of $1 \mu \mathrm{m}$ filtered seawater, and were gently agitated with sterile air pumped at approximately 2 bubbles second ${ }^{-1}$ through a $23 \mathrm{~cm}$ Pasteur pipette resting on the bottom of a $4 \mathrm{l}$ glass jar. Unless otherwise specified, cultures were cleaned every second day and fed the diatom Phaeodactylum tricornutum at a final concentration of $1 \times 10^{5}$ cells $\mathrm{ml}^{-1}$ after each cleaning.

Experimental substrata consisted of biofilm and conspecifics constructed and maintained as described in Toonen \& Pawlik (1996, 2001a). Settlement assays using a sample of 25 larvae were performed $7 \mathrm{~d}$ postfertilization as described in Toonen \& Pawlik (1996, 2001a), and for each experiment, there were 12 replicates of 25 larvae each (run simultaneously) for each substratum. At the end of the experiment, after being rinsed gently with $1 \mu \mathrm{m}$ filtered seawater to remove any remaining larvae, we examined each slide through a dissecting microscope and counted settled juveniles (identified by rudimentary crown and Tube Formation - see Scheltema et al. 1981 for photographs) as they were individually removed.
Settlement of larvae occurs only on surfaces coated with an organic/bacterial film, hereafter called simply biofilm, and the requirement of a biofilm for settlement has also been documented for the congeneric worm Hydroides elegans (e.g. Hadfield et al. 1994, Bryan et al. 1997, Beckmann et al. 1999, Harder \& Qian 1999, Unabia \& Hadfield 1999). Unlike H. dianthus however, the larvae of which are highly gregarious (Scheltema et al. 1981), response to bacterial films alone appears to explain patterns of settlement for $H$. dianthus in Hawaii (Hadfield et al. 1994, Unabia \& Hadfield 1999), but not for this species in Hong Kong where it settles preferentially in response to both conspecific worms (Bryan et al. 1997) and the arborescent bryozoan Bugula neritina (Bryan et al. 1998) as well as dissolved free amino acids and the bacterial films associated with them (Beckmann et al. 1999, Harder \& Qian 1999). Even in the presence of a metamorphic inducer, a water-soluble chemical cue which we have isolated from the bodies of live conspecifics but not the tubes which they inhabit, gregarious settlement of $H$. dianthus larvae occurs only on biofilmed surfaces (Toonen \& Pawlik 1996, 2001a). Larvae settling in response to conspecifics appear to require cues associated with both the bacterial/organic biofilm and the chemical inducer released by live conspecific adults in order to settle and metamorphose (Toonen 1993, Toonen \& Pawlik 1996). Larvae and settled juveniles are not capable of eliciting gregarious settlement until approximately $96 \mathrm{~h}$ after metamorphosis, and the metamorphosis of some proportion of larvae assayed in $24 \mathrm{~h}$ settlement assays does not alter the nature of the intended cue (Toonen \& Pawlik 1996). We found no evidence of differential bacterial growth associated specifically with live conspecific adults, and there was no indication that variation in bacterial films among substrata contributes to differences in larval settlement in response to biofilm and conspecifics (Toonen \& Pawlik 2001a).

Larval growth. We started 15 cultures from single dams and maintained each culture as outlined above to examine the growth pattern of larvae throughout an extended period of larval culture. To determine mean larval length, samples of at least 25 larvae were removed from each culture and added to a Falcon $35 \times$ $10 \mathrm{~mm}$ petri dish filled with isotonic $\mathrm{MgCl}_{2}$ and stored at $4^{\circ} \mathrm{C}$ for 6 to $8 \mathrm{~h}$ to completely relax the larvae. Twenty-five relaxed larvae were then measured for maximum length on an Olympus $\mathrm{CH}-2$ compound microscope equipped with a calibrated ocular micrometer at the maximum magnification possible for a given larval length. Samples of larvae were measured each day throughout the first $10 \mathrm{~d}$ of culture (until growth appeared to asymptote), and each tenth day thereafter until the experiment was terminated on Day 60. 
Larval starvation. Because the desperate larva hypothesis is really an energetic argument, we wanted to test whether larval desperation occurred as a result of energetic limitations rather than prolonged planktonic duration. To determine if we could elicit a decrease in substratum-specificity in response to food deprivation, we used a mixed-parentage culture, maintained in 41 jars with 31 of $1 \mu \mathrm{m}$ filtered seawater as outlined above, with the exception that cultures were cleaned and assayed daily throughout the experiment. Each day, a sample of at least 30 larvae was relaxed and measured as described above. The entire culture of larvae was then filtered down into a single small volume and 9 samples of 25 larvae each were removed for assay; the remainder were rinsed into a $10 \mathrm{~cm}$ glass dish containing a single biofilmed slide. Dishes of larvae were placed on a shaker table rotating at $50 \mathrm{rpm}$ for $1 \mathrm{~h}$, then the slides were removed, rinsed, and scored as previously described. The larvae remaining in the dish were returned to a clean culture jar and fed. After $10 \mathrm{~d}$ (the time at which larval growth appeared to asymptote in the larval growth experiment described above), the cultures were each split in half: half were maintained as previously described, while the other half were starved in an attempt to exhaust larval energetic reserves. Once split, cultures were kept under similar conditions in terms of food concentration and larval densities by maintaining halved cultures in 21 jars with $1.5 \mathrm{l}$ of $1 \mu \mathrm{m}$ filtered seawater as described previously.

Although not analogous, this is at least conceptually similar to the depletion of energetic reserves experienced by lecithotrophic larvae at the end of their planktonic period and, if larval desperation is driven by energetics rather than planktonic period per se, should result in decreased substratum-specificity among starved larvae. Larvae in starved cultures were cleaned daily and otherwise treated exactly as the fed cultures, but were not fed after each cleaning. Although our cultures were obviously not axenic and bacterial feeding by the congener Hydroides elegans was sufficient to complete larval development and metamorphosis (Gosselin \& Qian 1997), withholding phytoplankton food from these larvae accomplished our goal of starvation: larvae of $H$. dianthus lost competence and began to die in culture after only $4 \mathrm{~d}$ phytoplankton deprivation. Because the larvae stopped responding to experimental substrata and began to die in culture, we were convinced that they had been stressed energetically at this point, and recommenced feeding to see whether the surviving larvae would be less discriminating in their settlement choice than conspecifics that had been fed throughout the planktonic period. After $18 \mathrm{~d}$ the experiment was terminated because of the low number of larvae remaining in the starved cultures.
Differences in mean larval length between fed and starved cultures on a given day were analyzed with a Student's $t$-test employing a Bonferroni correction for multiple tests (Snedecor \& Cochran 1989). Percentage data for larval response to biofilm and conspecifics were arcsine square-root-transformed prior to testing for conformity of data to assumptions of parametric statistics (Shapiro-Wilks test for normality and Bartlett's test for homoscedasticity, $\alpha=0.01$ ). Transformation normalized the data in each case, but could not equalize the variance of larval settlement, violating the assumption of homoscedasticity for parametric statistics. Thus, significances of differences in settlement between days in response to biofilm and conspecifics were each tested separately using a nonparametric Kruskal-Wallis test on rank data (Sokal \& Rohlf 1981). Significance of post hoc comparisons among mean settlement used the Tukey-Kramer honestly significant differences (HSD) method because although HSD is still conservative, it yields results which are closest to the intended significance level $(\alpha)$ of the various unplanned comparisons techniques (Sokal \& Rohlf 1981).

Larval feeding regime. We also examined the patterns of larval settlement among larvae maintained with varying concentrations of phytoplankton to determine if feeding regime affected larval settlement patterns. The zygotes from a large mixed-parentage culture were split into 3 feeding concentration groups: low food $\left(10^{4}\right.$ cells ml ${ }^{-1}$ culture $)$, moderate food $\left(10^{5}\right.$ cells ml-1 ${ }^{-1}$ and high food $\left(10^{6}\right.$ cells ml $\left.{ }^{-1}\right)$. These feeding concentrations were selected to simulate the normal range of phytoplankton cell densities occurring naturally in Banks Channel, as estimated from the chlorophyll a content (e.g. Cahoon et al. 1994, 1998, Hubertz \& Cahoon 1999, Mallin et al. 1999). Cultures maintained for evaluating the effect of algal food concentration on larval settlement were cleaned and added daily at the appropriate concentration; cultures were otherwise maintained as described above. Each day, 12 samples of 25 larvae from each feeding regime were assayed for their settlement in response to biofilm and conspecifics, and a second sample of at least 50 larvae was removed and relaxed for growth measurements (both as described above).

Larval length data could not be transformed to meet the homogeneity of variance assumption of parametric statistics (Bartlett's test, $\mathrm{p} \ll 0.001$ ). We therefore used the nonparametric Kruskal-Wallis rank data to test for differences in mean larval size between feeding regimes (Sokal \& Rohlf 1981). Post hoc comparisons among means were analyzed with a Student's $t$-test corrected for unequal variances $\left(t^{\prime}\right)$ using a Bonferroni correction (Snedecor \& Cochran 1989), and the critical value and degrees of freedom being derived from a weighted average of the 2 samples being tested (Sokal 
\& Rohlf 1981). Differences among arcsine-transformed percentage settlement in response to biofilm and conspecifics within each feeding regime were likewise tested using the $t^{\prime}$-test and Bonferroni correction (Snedecor \& Cochran 1989).

Settlement as a function of larval size class. We noted that even larvae in single dam cultures were not homogeneous in terms of size, and wondered if differences which led to the variation in larval size could also contribute to variation in larval settlement preference among individual larvae. Many studies have documented some correlation between larval size and energy content (e.g. McEdward \& Chia 1991, Jaeckle 1994, Levin \& Bridges 1994, Qian 1994, de Jong-Westman et al. 1995), and given the observed variation in larval size distributions among the offspring of individual females, we wanted to test whether energetic or growth differences among individual larvae that resulted in size variation could potentially account for the difference in larval settlement observed on these experimental substrata. We hypothesized that larvae may differ energetically as a result of genetic, behavioral or microhabitat-use differences, even when cultured under identical conditions in the laboratory, and explored whether energetic differences leading to larval size-class variation at competency resulted in predictable patterns of differential larval settlement. To determine whether there were any size-class-specific differences in larval response to experimental substrata, we examined settlement of larvae from a mixedparentage culture of the gametes from $\sim 25$ worms. Each culture was maintained in isolation as described above, and after $7 \mathrm{~d}$ larvae were separated into size classes using a descending filter series $(153,127,100$, 80 and $52 \mu \mathrm{m}$ ) to collect those larvae greater than the mesh size of the filter. Because there were no larvae retained by the $153 \mu \mathrm{m}$, it was omitted from all subsequent analyses. It is important to note that the larval sizes reported herein refer to the maximum larval length, and that when larvae are being rinsed through a filter mesh it is likely that larval width rather than length determines whether an individual is retained. Twelve samples of 25 larvae were then removed from each size category and assayed for response to each biofilm and conspecifics in no-choice assays as described above. Once again, there was no transformation that resulted in homogeneity of variances of larval response to experimental substrata; thus, differences between settlement in response to biofilm and conspecifics were each tested separately using a Kruskal-Wallis test, and significance of post hoc comparisons among means used the Tukey-Kramer HSD method (as above).

Larval size distribution. Because energetic manipulation was unsuccessful in eliciting decreased substra- tum-specificity among the larvae of Hydroides dianthus, there appeared to be differences in the mean settlement of larvae separated on the basis of size, we examined clutches of larvae derived from individual dams to determine if there were any obvious correlates with nongregarious settlement. As described above, we first measured the mean size of eggs spawned by 6 individual dams and a mixed-parentage culture; each culture was maintained in isolation, and after $7 \mathrm{~d}$ larvae were separated into size classes using a descending filter series $(127,100,80$ and $52 \mu \mathrm{m})$. Larvae were then back-washed out of the filters, counted to determine the proportion of larvae which were retained by each filter mesh-size, and 12 samples of 25 larvae each were used in settlement assays testing response to biofilm and conspecifics. Differences in mean larval size among dams conformed to assumptions of parametric statistics (as outlined earlier) and was therefore tested using a 1-way ANOVA. Again there was no transformation that resulted in homogeneity of variances of larval response between experimental substrata, thus differences among dams in larval response to biofilm and conspecifics (results of which each conformed to parametric assumptions) were each tested separately with a 1-way ANOVA; post hoc comparisons among means were again done using the Tukey-Kramer HSD method (Sokal \& Rohlf 1981).

Life-history correlates and nongregarious settlement. To examine possible life-history correlates of gregarious and nongregarious settlement of larvae, we measured a number of obvious life-history characters from dams used in 200 random crosses of field-collected Hydroides dianthus. The characters we measured included: (1) dam body length (from the top of the collar to the end of the pygidium, i.e. this length does not include the branchial crown); (2) total number of eggs spawned (when induced by tube fracture as described above); (3) mean diameter of spawned eggs (measured as for the larvae); (4) mean larval length at 7 d post-fertilization; (5) mean percentage settlement of larvae in response to conspecifics at $7 \mathrm{~d}$ post-fertilization (12 samples of 25 larvae assayed as described above); (6) percentage of total culture (less those individuals removed for measurement or settlement assays as required) that settled in response to biofilm at $7 \mathrm{~d}$ post-fertilization. Percentage data were arcsinesquare root-transformed prior to analyses but other measures were untransformed (see Table 1). For simplicity in differentiating those larvae that settled nongregariously in response to biofilm from those that settled gregariously in response to conspecifics, we will hereafter use the terms we have coined previously based on the presumed ecological outcome of these larval responses: founders and aggregators, respectively (Toonen \& Pawlik 1994). Because these data 


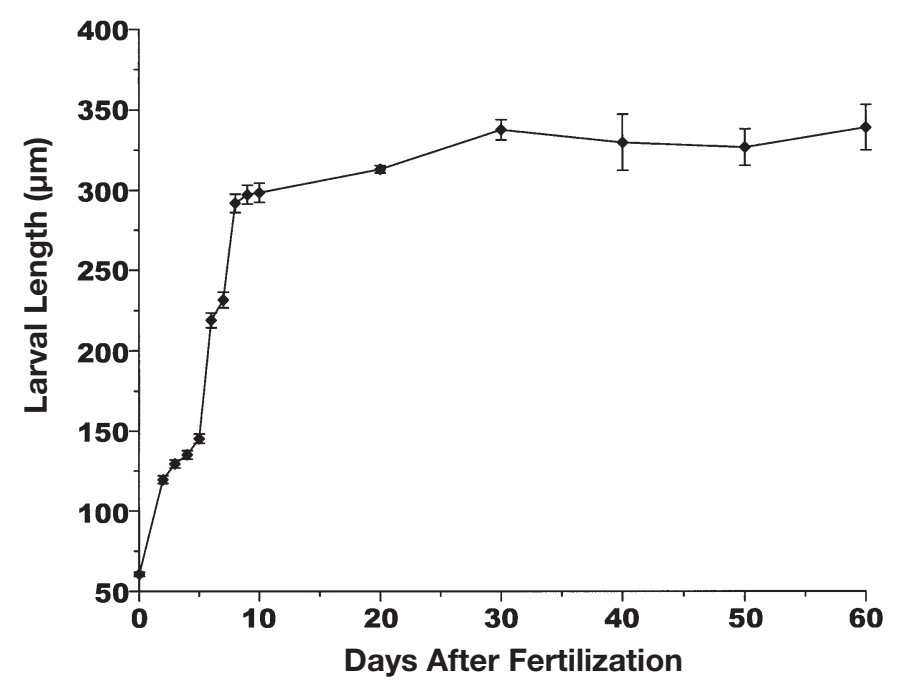

Fig. 1. Hydroides dianthus. Mean body length of samples of relaxed larvae $\left(\mathrm{n}=15\right.$ replicate cultures, 25 larvae culture ${ }^{-1}$ $\pm 1 \mathrm{SE}$ ) maintained in culture through planktonic period of $60 \mathrm{~d}$

failed both a Shapiro-Wilks test for normality and Bartlett's test for homoscedasticity, we also used a BoxCox transformation to determine iteratively the closest fit for each character measured to assumptions of parametric statistics (Sokal \& Rohlf 1981) prior to repeating these analyses to test for statistical significance of the associations (see Table 2). Dam body length required no transformation to meet assumptions of parametric assumptions, and was therefore used in these analyses untransformed. Box-Cox iteration (using JMP for Windows SAS Institute Version 3.1.6.2) provided the following functions for the remaining characters as the best-fit transformation to parametric assumptions: (1) $\ln$ (total number of eggs spawned) $\times 61.3207$; (2) $\left([\text { mean diameter of spawned eggs }]^{5}-1\right) \times 122.1765$; (3) ([mean larval length $\left.]^{5}-1\right) \times 550.1023$; (4) ([mean \% aggregators@d7 $\left.]^{0.2}-1\right) \times 0.0146 ;$ (5) ln (\% founders @ d7) $\times 0.1974$.

Simple pairwise correlations between all combinations of these characters were computed as well as partial correlations in which the relationship between a pair of traits is determined with the effect of all other characters being held constant (Sokal \& Rohlf 1981). Significance of simple pairwise correlations was tested using F-ratios, while significance of partial correlation coefficients was tested with a modified Student's $t$-test, $t^{\prime}$ (Sokal \& Rohlf 1981). A number of significant correlations were found, and we examined the relative contribution of each to the proportion of founding settlers in a given spawn in the hope of finding some obvious life-history character to examine for a proximate mechanism of determining larval settlement preference.
Therefore, we used a path analysis (both inclusion and exclusion) to determine which parameters explained the majority of the variation in our data (Sokal \& Rohlf 1981).

\section{RESULTS}

\section{Growth of fed larvae}

The mean egg size spawned by Hydroides dianthus was $60.7 \pm 1.3(\mathrm{SE}) \mu \mathrm{m}$, and larval growth was virtually linear for the first $8 \mathrm{~d}$ post-fertilization, at which point larvae averaged $291.92 \pm 5.78$ (SE) $\mu \mathrm{m}$ (Fig. 1). After $8 \mathrm{~d}$ of growth, larvae show a marked decrease in the growth rate and maintained a mean larval length of approximately $300 \mu \mathrm{m}(297.33 \pm 5.93$ B $338.94 \pm$ $14.06 \mu \mathrm{m})$ throughout the remainder of the experiment. Despite continued feeding and prolonged planktonic existence, larvae do not increase beyond this asymptotic larval length, at which the majority of larvae reach competency.

\section{Effects of starvation on larval growth and settlement}

Similar to fed larvae, the growth of starved larvae reached an asymptote of roughly $300 \mu \mathrm{m}$, and the first settlement coincided with larvae reaching this asymptotic size (Fig. 2). Settlement in response to biofilm exposure of the entire larvae culture (Fig. 2B) paralleled that observed in the assays using samples of 25 larvae (Fig. 2C). However, unlike the assays using the samples (Fig. 2C), after Day 10 larval response to biofilm in whole-culture assays dropped to values indistinguishable from zero (Fig. 2B).

Larvae assigned to the starved cultures began to decrease in size within $24 \mathrm{~h}$, by which time starved larvae were significantly shorter than those larvae remaining in the fed cultures $(t=5.98, \mathrm{df}=29, \mathrm{p}<0.05)$. Larval size in starved cultures decreased consistently throughout the period of starvation, and $4 \mathrm{~d}$ after feeding had ceased larvae were approximately 20\% smaller in starved than in fed cultures (Fig 2A). Mean larval length increased again rapidly when feeding was resumed on Day 14 (Fig. 2A), but it took the larvae several days to recover completely from the $4 \mathrm{~d}$ food deprivation. From Days 12 through 16, larvae in starved cultures were significantly shorter than larvae in fed cultures ( $t=4.63$ to $8.25, \mathrm{df}=29, \mathrm{p}<0.05)$, but by Day 17 there was no difference in mean larval length between fed and starved cultures $(t=0.17$, df $=29, \mathrm{p}>$ 0.05).

After splitting the larvae into fed and starved groups, there was significant variation in larval settlement in 
response to conspecifics between fed (Kruskal-Wallis $H=14.68, \mathrm{df}=7, \mathrm{p}<0.05)$ and starved $(H=47.57, \mathrm{df}=$ $7, \mathrm{p}<0.05$ ) cultures (Days 10 to 18). Settlement in response to biofilm varied significantly across days for the starved cultures $(H=21.49$, $\mathrm{df}=7, \mathrm{p}<0.05)$, however larvae from fed cultures did not differ significantly in their response to biofilm throughout the entire experimental treatment period $(H=8.28, \mathrm{df}=7$, $\mathrm{p}>0.05$ ). Post hoc comparison of means among these groups indicates that the significance derives from both the significantly decreased settlement observed in all cultures on Days 11 and 12, and from the cessation of settlement among starved larvae by Day 14 (Fig. 2C).

Mean settlement rate in both fed and starved cultures fell at the start of the experimental treatment after Day 10 (Fig. 2C). However, it was the difference between settlement rate in fed versus starved cultures that was of interest in this experiment. Thus, although the response of larvae to conspecifics and biofilm in the fed cultures also dropped at Day 11 (after $1 \mathrm{~d}$ starvation), this value should be considered the baseline for the settlement of larvae in the starved cultures, and there is in fact no significant difference between the response of larvae to conspecifics for samples of larvae drawn from the fed and starved cultures on Day 11 (HSD, $Q=3.13, \mathrm{p}>0.05$ ). Settlement of larvae drawn from starved cultures had decreased significantly in response to conspecifics by Day $12(\mathrm{HSD}, Q=3.13$, $\mathrm{p}$ > 0.05 ), and continued to decrease until larvae ceased to settle on Day 14 (Fig. 2C). Larvae began to settle in response to conspecifics within $24 \mathrm{~h}$ of resuming feeding (Fig. 2C), but settlement remained significantly lower among larvae from starved cultures than from fed cultures until Day 16 (HSD, $Q=3.13, \mathrm{p}>0.05$ ). Settlement of larvae from fed and starved cultures did not differ significantly in response to either biofilm or conspecifics on Days 17 or 18 (HSD, $Q=3.13, \mathrm{p}>0.05$ ).
Fig. 2. Hydroides dianthus. Effect of starvation on body size and settlementspecificity of competent larvae in laboratory cultures. Larvae were cultured together through the first $10 \mathrm{~d}$ after fertilization, at which point the cultures were split and half were fed and half were starved. The starvation treatment was started on Day 10, feeding was resumed on Day 14; cessation and resumption of feeding are indicated on abscissa of each plot (^). (A) Mean (+1 SE, $\mathrm{n}=30$ ) body length of samples of larvae from each treatment; ${ }^{*}$ samples among which means were significantly different; overscored bars: no significant difference. (B) Mean $(+\mathrm{SE})$ number of larvae settling in response to biofilm when the entire culture of larvae was exposed to biofilmed slides daily ( $\mathrm{n}=3$ replicate cultures). (C) Mean $(+\mathrm{SE}, \mathrm{n}=12)$ percentage of settlement of samples of 25 larvae in response to biofilm and conspecifics in $24 \mathrm{~h}$ no choice assays
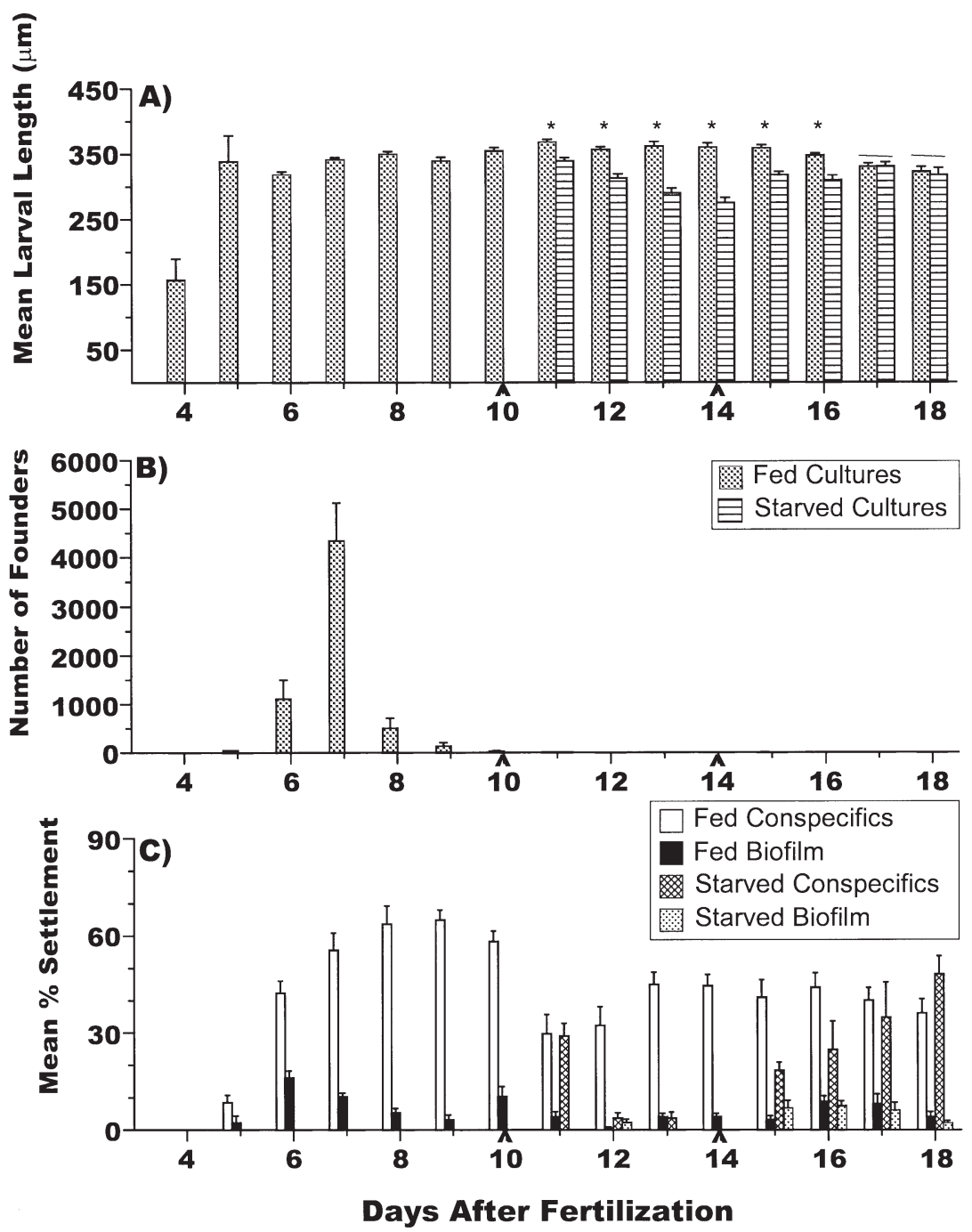


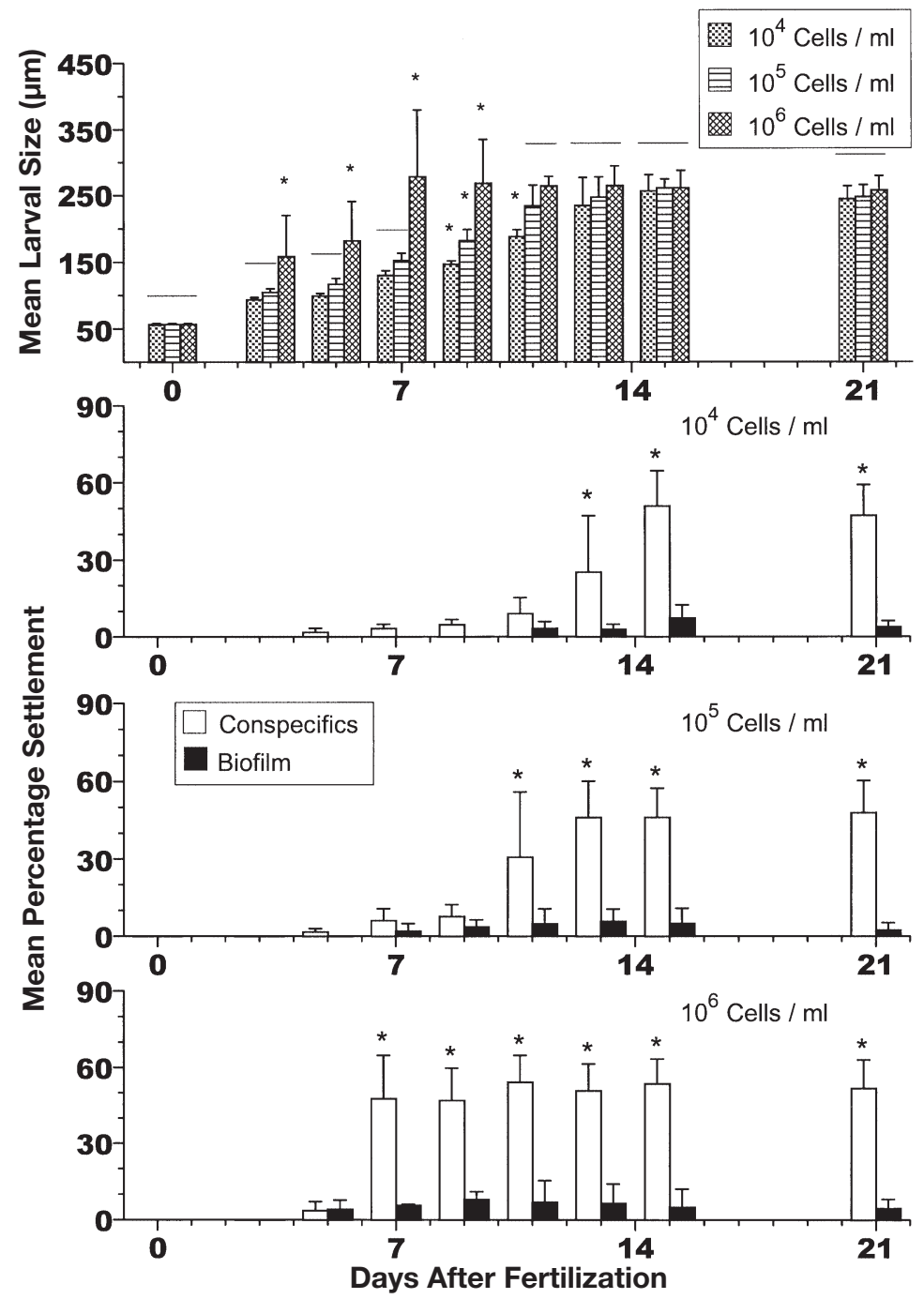

Fig. 3. Hydroides dianthus. Effect of feeding concentration on mean larval size and settlement preferences of larvae. Top graph: mean (+1 $\mathrm{SE}, \mathrm{n}=50$ ) body length of samples of larvae cultured on low $\left(10^{4}\right.$ cells $\left.\mathrm{ml}^{-1}\right)$, medium $\left(10^{5}\right.$ cells $\left.\mathrm{ml}^{-1}\right)$ or high $\left(10^{6}\right.$ cells $\left.\mathrm{ml}^{-1}\right)$ feeding regimes; ${ }^{*}$ means significantly different from the means of the other treatments; overscored bars: no significant difference. Bottom graphs: mean $(+1 \mathrm{SE}, \mathrm{n}=12)$ percentage settlement of samples of 25 larvae in response to biofilm and conspecifics for each feeding concentration

with those in the high food treatment $\left(t^{\prime}=\right.$ 1.94, $\mathrm{df}=49, \mathrm{p}>0.05)$, but those in the low food treatment were still significantly smaller than those in either the moderate or high food treatments $\left(t^{\prime}=4.05\right.$ and 9.60, $\mathrm{df}=49, \mathrm{p}<0.05)$. On Day 13, however, there were no significant differences among mean larval length between any of the feeding regime treatments $\left(t^{\prime}=0.54\right.$ to 1.32, df $=49, \mathrm{p}>0.05$ ). Differences in larval length prior to Day 7 and after Day 13 were not significant $(H=0.62$ to 2.63 , $\mathrm{df}=2, \mathrm{p}>0.05$ ).

Differences in larval settlement patterns mirrored the differences in mean larval length outlined above. Larvae in the highest food treatment became competent earliest, and there was a significant difference in mean response to biofilm and conspecifics from Day 7 through $21\left(t^{\prime}=5.92\right.$ to $9.00, \mathrm{df}=11, \mathrm{p}<0.05)$. In the moderate food treatment, settlement of larvae in response to biofilm and conspecifics first increased at Day 11, but was not significantly different between substrata until Day $13\left(t^{\prime}=6.05\right.$, df $\left.=11, \mathrm{p}<0.05\right)$. Settlement in the low food treatment again followed the pattern seen with larval growth, and settlement first increased at Day 13, but was not significantly different between biofilm and conspecifics until Day $15\left(t^{\prime}=\right.$ 6.69 , df $=11, p<0.05)$. In each case it was an increase in larval settlement among those exposed to conspecifics rather than a change in the larval settlement among those exposed to biofilm that led to significant differences between larval responses to experimental substrata (Fig. 3).

\section{Settlement as a function of larval size class}

Larvae separated into the 4 size classes

\section{Larval feeding regime}

Larvae fed at the high food concentration $\left(10^{6}\right.$ cells $\mathrm{ml}^{-1}$ ) grew more quickly than those maintained at lower food concentrations (Fig. 3A), and by Day 7 larvae in high food cultures were significantly larger than those in the moderate or low food treatments $\left(t^{\prime}=3.77\right.$, $\mathrm{df}=49, \mathrm{p}<0.05)$. On Day 9 larvae in all feeding regimes were significantly different in mean body length $\left(t^{\prime}=3.78\right.$ to $\left.4.56, \mathrm{df}=49, \mathrm{p}<0.05\right)$. By Day 11, larvae in the moderate food treatment had caught up showed significant differences in their mean settlement response of larvae in response to conspecifics $(H=8.44, \mathrm{df}=3, \mathrm{p}<0.05)$ but not in response to biofilm $(H=1.60, \mathrm{df}=3, \mathrm{p}>0.05)$. The differences among response to conspecifics appear to be due to the reduced settlement of larvae on conspecifics in the < $79 \mu \mathrm{m}$ size class (retained on $52 \mu \mathrm{m}$ mesh) compard to the other 3 size classes (Fig. 4). However, the TukeyKramer HSD comparisons found no groups among which the means were significantly different $(Q=2.62$, $\mathrm{p}>0.05)$. 


\section{Larval size distribution}

Eggs spawned by individual females differed in mean diameter (Fig. 5A), but not significantly $(H=1.73, \mathrm{df}=6, \mathrm{p}>0.05)$. Despite the fact that there were no significant differences among the mean size of eggs spawned, the size distribution of larvae after $7 \mathrm{~d}$ culture were substantially different among dams (Fig. 5B). Larval size distribution ranged from $>90 \%$ of larvae in a single size class (Dam \#1) to an almost even distribution of larvae among the various size classes (Dam \#4 and Mix). These size-distribution differences did not translate into differences in larval settlement preference, however, and neither the mean response of larvae to conspecifics $(H=$ 11.17, $\mathrm{df}=6, \mathrm{p}>0.05)$ nor to biofilm $(H=$ $4.31, \mathrm{df}=6, \mathrm{p}>0.05$ ) at Day 7 was significant (Fig. 5C). However, examination of the settlement patterns of larvae within each size class across dams revealed that the mean percentage settlement in response to conspecifics did differ significantly between size classes $(H=10.87, \mathrm{df}=3, \mathrm{p}<0.05)$. There was again no difference among size classes in the mean response of larvae to biofilm in these assays $(H=1.96, \mathrm{df}=3, \mathrm{p}>$ 0.05). A post hoc comparison using TukeyKramer's HSD found that mean settlement in response to conspecifics among larvae in the $>127 \mu \mathrm{m}$ size class $(7.29 \pm 3.13 \%)$ was significantly less than that of larvae in the $<79 \mu \mathrm{m}(26.50 \pm 1.01 \%)$ and 100 to $126 \mu \mathrm{m}$ $(22.11 \pm 1.81 \%)$ size classes. Again, the significance resulted from a decreased response of larvae to conspecifics rather than an increased response of larvae to biofilm, but in direct contrast to the results from the

Fig. 5. Hydroides dianthus. Differences in mean size of eggs spawned, size distribution of competent larvae, and settlement of competent larvae in response to biofilm and conspecifics among 6 individual dams and a mixed-parentage culture. (A) Mean (+1 SE, $\mathrm{n}=25$ ) diameter of eggs spawned. (B) Proprtion of larvae retained on a descending series of Nytex mesh filters at $7 \mathrm{~d}$ post-fertilization. (C) Mean (+1 $\mathrm{SE}, \mathrm{n}=12$ ) percentage settlement of samples of 25 larvae in response to biofilm and conspecifics from each spawn; groups among which the means did not differ significantly (HSD, $\alpha=0.05$ ) are denoted by shared letters

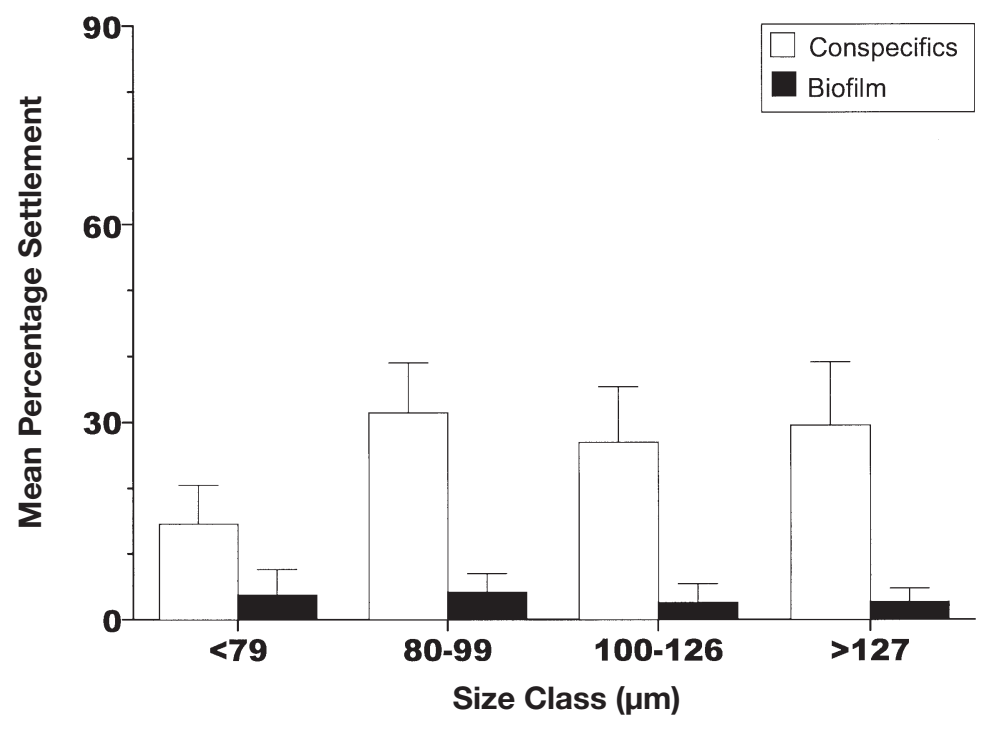

Fig.4. Hydroides dianthus. Mean (+1 $\mathrm{SE}, \mathrm{n}=12)$ percentage settlement of samples of 25 larvae in response to biofilm and conspecifics as a function of size-class. Competent larvae were separated by a descending series of Nytex mesh filters and assayed as described in 'Materials and Methods'
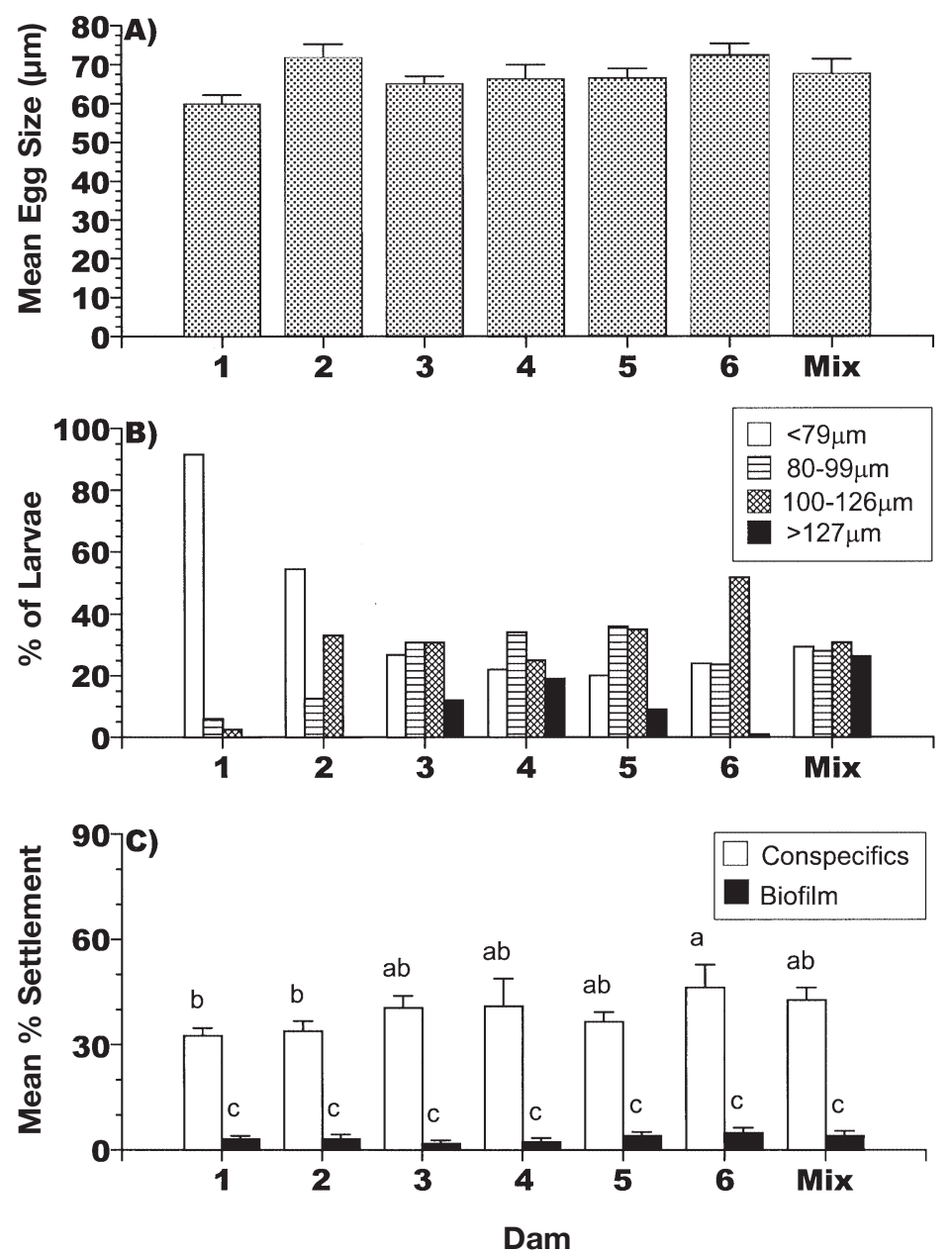
Table 1. Hydroides dianthus. Correlations of life-history characters measured for 200 random crosses among field-collected individuals. Values above diagonal are simple pairwise correlation coefficients, values below diagonal are partial correlation coefficients in which the correlation of each variable pair is determined with all other variables held constant. Percentages were arcsinetransformed, while other data were untransformed prior to analysis. Significance $(\alpha=0.05)$ of pairwise correlation coefficients were tested using F-ratios, while significance of partial correlation coefficients was determined using a modified Student's $t$-test, $t^{\prime}$ (see 'Materials and methods'); significant results are given in bold. Correlations between characters for which the slope of the relationship was negative are denoted as negative values

\begin{tabular}{|c|c|c|c|c|c|c|}
\hline & $\begin{array}{c}\text { Dam } \\
\text { body length }\end{array}$ & $\begin{array}{c}\text { Mean } \\
\text { egg diameter }\end{array}$ & $\begin{array}{c}\text { Total \# } \\
\text { eggs spawned }\end{array}$ & $\begin{array}{c}\text { Mean } \\
\text { larval length }\end{array}$ & $\begin{array}{c}\text { \% settlement } \\
\text { @ Day } 7\end{array}$ & $\begin{array}{c}\% \\
\text { founders }\end{array}$ \\
\hline $\begin{array}{l}\text { Dam body } \\
\text { length }\end{array}$ & - & 0.14 & 0.51 & 0.10 & 0.11 & -0.15 \\
\hline $\begin{array}{l}\text { Mean } \\
\text { egg diameter }\end{array}$ & 0.11 & - & 0.19 & 0.52 & -0.39 & -0.07 \\
\hline $\begin{array}{l}\text { Total \# } \\
\text { eggs spawned }\end{array}$ & 0.30 & 0.26 & - & 0.38 & 0.20 & -0.43 \\
\hline $\begin{array}{l}\text { Mean } \\
\text { larval length }\end{array}$ & -0.17 & 0.41 & 0.30 & - & -0.12 & -0.14 \\
\hline $\begin{array}{l}\text { \% settlement } \\
\text { @ Day } 7\end{array}$ & 0.03 & -0.31 & -0.07 & 0.05 & - & 0.01 \\
\hline $\begin{array}{l}\% \\
\text { founders }\end{array}$ & 0.05 & 0.29 & 0.30 & 0.14 & -0.23 & - \\
\hline
\end{tabular}

mixed-parentage culture, the size class that appeared to drive the relationship was the largest size class (Fig. 5D) rather than the smallest (Fig. 4).

\section{Life-history correlates and nongregarious settlement}

Table 1 presents a summary of the pairwise correlations and partial correlation coefficients calculated for the life-history traits which we measured in 200 random pairings of field-collected individuals. Five significant correlations were found among the life-history traits we measured (Table 2). Because there are good reasons to believe that some or all of these life-history characters may co-vary, however, we also calculated partial correlations in order to keep the effects of other characters constant (Sokal \& Rohlf 1981). Four of the partial correlation coefficients were found to be significant ( $t>1.96, \mathrm{df}=48, \alpha=0.05)$; the proportion of aggregators per spawn was no longer correlated with mean egg diameter (Table 2 ).

We subsequently did a path analysis (Sokal \& Rohlf 1981) after standardizing the measures of these variables $(x=0, \mathrm{SD}=1.0)$ to determine the relative contri-

Table 2. Hydroides dianthus. Significant pairwise (A) and partial (B) correlation coefficients of life-history characters measured for 200 random crosses among field-collected individuals. Data were transformed by Box-Cox iteration to best-fit assumptions of parametric statistics prior to statistical analysis (see 'Materials and methods'). Significance $(\alpha=0.05)$ of pairwise correlation coefficients was tested using F-ratios, while significance of partial correlation coefficients was determined using a modified Student's $t$-test, $\left(t^{\prime}\right)$. Correlations between characters for which the slope of the relationship was negative are denoted as negative values

\begin{tabular}{|c|c|c|c|c|}
\hline Measured characters & $\mathrm{n}$ & $\mathrm{r}^{2}$ & $F$ & $\mathrm{p}$ \\
\hline \multicolumn{5}{|l|}{ (A) Significant pairwise correlations } \\
\hline Total \# of eggs spawned $\times$ Dam body length & 200 & 0.26 & 17.18 & $<0.05$ \\
\hline Mean larval length $\times$ Mean egg diameter & 200 & 0.28 & 18.63 & $<0.05$ \\
\hline Mean larval length $\times$ Total \# eggs spawned & 200 & 0.15 & 8.18 & $<0.05$ \\
\hline \% settlement@ Day $7 \times$ Mean egg diameter & 200 & -0.16 & 8.85 & $<0.05$ \\
\hline$\%$ founders $\times$ Total \# eggs spawned & 200 & -0.19 & 10.92 & $<0.05$ \\
\hline \multicolumn{5}{|l|}{ (B) Significant partial correlation coefficients } \\
\hline & $\mathrm{n}$ & $r^{2}$ & $t^{\prime}$ & $\mathrm{p}$ \\
\hline Total \# of eggs spawned $\times$ Dam body length & 200 & 0.30 & 7.83 & $<0.05$ \\
\hline Mean larval length × Mean egg diameter & 200 & 0.41 & 6.51 & $<0.05$ \\
\hline Mean larval length $\times$ Total \# eggs spawned & 200 & 0.30 & 5.39 & $<0.05$ \\
\hline$\%$ founders $\times$ Total \# eggs spawned & 200 & -0.86 & 9.53 & $<0.05$ \\
\hline
\end{tabular}


bution of each of these characters to predicting the proportion of founding larvae produced by a given female. Using either the criterion of Sokal \& Rohlf (1981) for the inclusion $(\alpha<0.05)$ or exclusion $(\alpha>0.10)$ of predictor variables, or a stepwise regression model (similar $\alpha$ values), we found that only the total number of eggs spawned (adjusted $r^{2}=0.17$ ) was included in either the path or multiple regression (using forward or backward elimination procedure) model (partial correlation coefficient $=-0.93, F=10.92, \mathrm{p}<0.05$ ).

\section{DISCUSSION}

\section{Testing the desperate larva hypothesis}

Growth of Hydroides dianthus larvae asymptotes at around $300 \mu \mathrm{m}$ in length, and despite a prolonged larval planktonic period the length of larvae did not change significantly from Days 10 through 60 (Fig. 1). Although variable in timing between experiments, larval response to experimental substrata coincides with larvae reaching this asymptotic size (Figs 1 \& 2), and ranged from 4 to $8 \mathrm{~d}$ post-fertilization throughout all assays we have performed on these tube worms. Regardless of the timing, however, upon reaching asymptotic size, settlement in response to both biofilm and conspecifics begins simultaneously (Fig. 2).

Together with results from our previous work (Toonen 1993, Toonen \& Pawlik 1994, 2001a), the data presented here demonstrate that larvae of the gregarious tube worm Hydroides dianthus exhibit both gregarious and nongregarious settlement concurrently in stillwater laboratory assays, and that nongregarious settlement always ceases prior to gregarious larval settlement. We hypothesize that the early termination of the response to biofilm is probably due to culling of a distinct subset of larvae willing to accept biofilm as a suitable substratum (Toonen \& Pawlik 2001a). These differences in larval settlement behavior are consistent across a variety of experimental treatments in which larvae have (1) no previous exposure to experimental substrata, (2) previous exposure to only biofilm, or (3) previous exposure to both adults and conspecifics (Toonen \& Pawlik 1994, 2001a). These results are diametric to the predictions of the desperate larva hypothesis, but the foundation of this hypothesis is really an energetic argument. Therefore, we examined the desperate larva hypothesis from an energetic standpoint for the feeding larvae of $H$. dianthus to determine if decreased substratum-specificity could be induced among competent larvae when faced with an energetic crisis.

We found that larvae settlement in response to biofilm and conspecifics was unaltered by either starving competent larvae (Fig. 2) or by maintaining cul- tures under variable feeding regimes (Fig. 3) throughout the precompetent period. Settlement of larvae in sample assays was significantly reduced in starved relative to fed cultures after only 2 d starvation (Fig. 2C), and both mean larval length and mean percentage settlement decreased consistently as a result of starvation. Mean larval size began to decrease immediately after feeding ceased (Fig. 2A). Larvae in starved cultures were significantly shorter after only $1 \mathrm{~d}$ without food, and $4 \mathrm{~d}$ after feeding stopped larvae were approximately $20 \%$ smaller in starved than in fed cultures. Rather than indiscriminate settlement, starvation appeared to result in a loss of larval competency; there was no renewed settlement of larvae in response to biofilmed slides among larvae in culture (Fig. 2B), and larval settlement in response to biofilm and conspecifics ceased completely after $4 \mathrm{~d}$ without food (Fig. 2C). Larvae became competent again after a single day of feeding (Fig. 2C), and larval length was not significantly different between fed and starved cultures $3 \mathrm{~d}$ after feeding resumed (Fig. 2A).

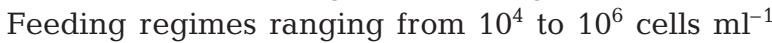
also appeared to have no qualitative effect on the settlement preferences of assayed larvae (Fig. 3). These feeding concentrations were selected to simulate the normal range of phytoplankton cell densities occurring naturally in Banks Channel, as estimated from several chlorophyll a content studies (Cahoon et al. 1994, 1998, Hubertz \& Cahoon 1999, Mallin et al. 1999). If larvae make a decision to settle based on energy reserves or on some impression of the ambient feeding environment in which they find themselves, we would expect to see some alteration in differential settlement on biofilm and conspecifics across the range of natural phytoplankton concentrations likely to be encountered in the field. Contrary to this prediction, however, larval settlement in response to conspecifics is significantly greater than that in response to biofilm at roughly the time that mean larval size reaches the asymptotic length (Fig. 3). For the low food concentration trial $\left(10^{4}\right)$, this took $15 \mathrm{~d}$, whereas for the high food concentration experiment $\left(10^{6}\right)$ it took only $7 \mathrm{~d}$ (Fig. 3). Despite timing differences, however, there was no qualitative differences in the pattern of larval settlement in response to biofilm and conspecifics in any of the feeding regime experiments. Results were similar for the spawns of 5 individual dams assayed in the same manner as for the mixed-parentage culture presented here (R. J. Toonen unpubl. data).

The patterns of settlement among larval size classes after $7 \mathrm{~d}$ culture does not suggest that differences in the growth rate or body size associated with the energetic state of larvae could account for nongregarious settlement among the larvae of Hydroides dianthus, either (Figs 4 \& 5). Variable settlement was nonsignificant in 
response to biofilm among both size classes (Fig. 4) and dams (Fig. 5), and in fact the overall significance of differences in larval settlement in both cases appears to be driven by a reduction in the percentage settlement in response to conspecifics among larvae of the smallest size class. Differences in larval feeding regime led to significant differences in larval size and rate of development (Fig. 3), but no alteration in the differential settlement of competent larvae. Similarly, within a given culture, differences among individual larvae that led to size variation (whether the result of energetic, genetic, microhabitat-use or chance factors) did not explain the patterns of differential settlement of larvae in response to biofilm and conspecifics documented here.

Both species of polychaetes used in the studies that originally proposed the desperate larva hypothesis Spirorbis borealis (Knight-Jones 1951, 1953) and Ophelia bicornis (Wilson 1953)-produce lecithotrophic (non-feeding) larvae that use yolk as an energy source. As lecithotrophic larvae age, they deplete a finite reserve of energy (the yolk), and it may be that the depletion of this energy reserve encourages decreased substratum-specificity among larvae. It is difficult to separate the effects of larval age and energy depletion in lecithotrophic larvae. Therefore, the desperate larva hypothesis might result not from the duration of the larval planktonic lifespan ('age'), but from the energetic 'desperation' of larvae that have used much of their yolk while unsuccessfully searching for a preferred substratum. Planktotrophic (feeding) larvae acquire food throughout their life in the water column, however, and may reach 'energetic desperation' at any point in their planktonic life. If decreased substratumspecificity were driven by energetic considerations, we would expect that energetically stressing competent planktotrophic larvae (e.g. by food limitation) would elicit a response similar to depletion of yolk in a lecithotrophic species. However, starving planktotrophic larvae of Hydroides dianthus did not decrease their substratum-specificity but instead reverted to a pre-competent state. Similar results have been reported for the sabellariid polychaete Phragmatopoma lapidosa californica, which also has planktotrophic larvae (Pawlik \& Mense 1994). Larvae of the mollusc Crepidula fornicata (Pechenik et al. 1996b) and the echinoid Encope michelini (Eckert 1995), however, still became competent to metamorphose while being starved, suggesting that the effect of starvation differs among species. Our data suggest that the larvae of $H$. dianthus must remain above some energetic threshold (which appears to coincide with an approximate larval length of $300 \mu \mathrm{m}$ ) to remain competent to settle; larval response to substrata decreased significantly after only $2 \mathrm{~d}$ without food, and ceased within $4 \mathrm{~d}$. Even among the larvae of $C$. fornicata, which still became compe- tent and settled throughout a $6 \mathrm{~d}$ period of starvation, settlement was significantly reduced by starvation (Pechenik et al. 1996b; but see also Pechenik et al. 1996a). Furthermore, starved larvae showed the same substratum preferences as did fed larvae. Thus, larval 'desperation' does not explain the colonization of uninhabited substrata by $H$. dianthus either on the basis of planktonic age or depletion of energetic reserves, and available evidence does not lead us to expect it in other planktotrophic species.

If the desperate larva hypothesis were driven entirely by energetic constraints rather than planktonic period per se, then we would expect that starving planktotrophic larvae to begin to exhibit decreased substratum-specificity as their reserves dwindled; we saw no evidence for decreased substratum-specificity in either food manipulation (Fig. 3) or starvation (Fig. 2) experiments. Likewise, factors leading to growth differences among individual larvae cultured under identical conditions in the laboratory did not seem to translate into detectable differences in larval settlement choice at competency (Figs 4 \& 5). When lecithotrophic larvae are confronted with a limited energy reserve the energetic barrier is concrete: there is no way to replenish consumed energy. Under these circumstances, it is likely to be adaptive for larvae to become less discriminatory as their energy reserves become depleted, because the exhaustion of their nutrient reserve is both finite and predictable. In species with planktotrophic larvae, however, feeding can replenish depleted food reserves. Thus, planktotrophic larvae may never have been selected to respond desperately to starvation episodes. If periods of starvation are rare or temporary in nature, the observed loss of competency (Jaeckle 1994, Pawlik \& Mense 1994, and this present study) could be adaptive because larvae could use available reserves (perhaps some necessary component for settlement is among the first to be resorbed) to 'wait out' periods of low food availability rather than settle indiscriminately. Toonen \& Tyre (unpubl. data) have developed a settlement model that formalizes the predictions of the desperate larva hypothesis and examines the consequences of larval energetic state on settlement decisions and the delay of metamorphosis in both feeding and non-feeding larvae. Other strategies to deal with the problem of temporary food limitation, such as direct uptake of dissolved organics from seawater, bacterivory, or reallocation of available reserves to attain or maintain metamorphic competence, may have evolved in other species (e.g. Jaeckle 1994, 1995 [review], Eckert 1995, Pechenik et al. 1996a,b, Gosselin \& Qian 1997, Moran 1999 [review]), and from the available data there does not appear to any consistent pattern of larval response to starvation across taxa. 


\section{Life-history correlates of nongregarious settlement}

We examined a number of obvious life-history characters (dam size, mean egg diameter, total number of eggs spawned, mean larval length, and percentage settlement of larvae at Day 7) for correlations with the proportion of founding settlers in a spawn as a first step to understanding patterns of nongregarious settlement in Hydroides dianthus. We examined the relationship between these characters in the hope that a strong correlation between some life-history character and founder production would suggest further avenues of research into the proximate mechanisms of determining larval settlement preference. Of the simple pairwise correlations, 5 were significant, but only 4 of the partial correlation coefficients were significant whether examining the raw (Table 1) or BoxCox iteration-transformed (Table 2) data. Correlations between several of the measured life-history characters (dam size, mean egg diameter, and mean larval length at Day 7) are unsurprising and similar to findings for a myriad of other species of marine invertebrates (reviews by Levin \& Bridges 1994, 1995, Jaeckle 1995, Bridges \& Heppell 1996, McEdward 1996, Moran 1999). Correlations between egg size and larval characteristics such as developmental rate, larval size, size at metamorphosis, etc., have been observed in many taxa of marine invertebrates, but appear to be poorly correlated with larval settlement patterns among planktotrophic larvae (e.g. Gotelli 1987, Sinervo \& McEdward 1988, Pepin \& Meyer 1991, reviews by Jaeckle 1995, Moran 1999). Among larvae in which initial egg size was reduced experimentally, juvenile size at metamorphosis was independent of initial size, and appears to have no ultimate effect on the substrate preference or juvenile size among recruiting juveniles (reviews by Jaeckle 1995, Moran 1999).

The only life-history character to show a significant relationship with the proportion of founders spawned was the total number of eggs spawned by a dam (Tables 1 \& 2). The pairwise correlations between number of eggs spawned, dam body length, mean larval length and the proportion founders could potentially inflate or deflate the individual relationships, and we therefore also calculated the partial correlation coefficients for each pair in addition to the simple pairwise correlations (Tables $1 \& 2$ ). There is obviously some interrelation between these factors, because the correlation between percentage settlement at Day 7 and mean egg diameter becomes nonsignificant when the other factors are held constant in the partial correlation analyses. The partial correlation coefficients suggest that there is a strong relationship between the remaining factors, however, even when the interrelationships of these life-history characters are taken into consideration. Both the path analysis and stepwise regression (forward or backward) found that the only character which is included in a best fit model of the proportion of founders produced is the total number of eggs spawned $(F=10.97$, $\left.r_{\text {adj }}^{2}=0.17, p<0.05\right)$, and inclusion of all measured characters only increases the proportion of explained variation by about $2 \%$. The actual relationship between egg number and larval settlement preference obviously requires further study, but although these results are far from conclusive, they suggest that there may be some interaction between the number of eggs spawned by a female and the propensity for larvae to settle in response to biofilm.

\section{Behavioral variability and consequences of nongregarious settlement in a gregarious species}

Together with the results of our previous work investigating the settlement of larvae of Hydroides dianthus (Toonen 1993, Toonen \& Pawlik 1994, 1996), this study suggests that settlement in response to biofilm and conspecifics occurs concurrently, and that neither previous experience nor larval energetic state appear to change the qualitative pattern of settlement among competent larvae of this species. Although we have been unsuccessful in determining the mechanism by which larval settlement preference is determined, the observed pattern of settlement indicates that individual larvae appear to differ in their response to substrata, and that even among sibling larvae some individuals are willing to accept biofilmed slides as a suitable habitat, whereas others additionally require the presence of living conspecific adults in order to settle. We propose that there must be a general 2-step process by which aggregations of sexually reproducing marine invertebrates typically develop: first, nongregarious settlers (which we have dubbed founders) colonize a suitable, but previously uninhabited substratum, then gregarious settlers (which we have dubbed aggregators) subsequently respond to the presence of those colonizing individuals. Like Raimondi \& Keough (1990), we lament the fact that variability in larval settlement is typically omitted in subsequent summaries of original works, and argue that the assumption implicit in such oversimplication is that larval variability is unimportant. Instead, we argue that larvae of gregarious species which settle on control substrata are not simply lost souls that made a potentially fatal mistake in their choice of substratum, but rather that settlement of some individuals apart from conspecifics may be an important outcome of natural selection. 
There are many studies, especially in the insect and ornithological literature, demonstrating that rather than being a consequence of error variance, diversity of population and individual patterns of migration and settlement behavior can be an important outcome of natural selection (reviewed by Dingle 1996). Empirical evidence for insects (e.g. Davis 1980, Dingle 1980), small mammals (e.g. McShea 1992), migratory birds (e.g. DeSante 1983, Ketterson \& Nolan 1983), stickleback fishes (e.g. Quinn \& Brodeur 1991), spiny dogfish sharks (e.g. McFarlane \& Beamish 1986), American eels (e.g. Helfman et al. 1987), and sockeye salmon (e.g. Leggett 1984, 1985, Quinn 1984, 1985, Quinn \& Brodeur 1991) all suggest that deviants from typical patterns of migration are important in their own right, and that colonization of new habitats and population range expansion are most likely the result of these vagrants (Dingle 1996). Straying of some proportion of offspring is therefore likely to be adaptive in heterogeneous conditions, because as the possibility of breeding failure increases, so does the advantage of producing some proportion of young that colonize new habitats (Dingle 1996).

Although more risky both in terms of habitat suitability and future mating success, founders have a 'head-start' on growth, and probably have a reasonable chance of becoming the nucleus of a new aggregation if they settle in a habitat that supports postmetamorphic survival and growth. This early settlement of founders may provide a significant fitness advantage, because gamete production is positively correlated with body size in Hydroides dianthus (Tables 1 \& 2) and initial growth may translate into a substantial fitness pay-off. Furthermore, Pullen \& LaBarbara (1991) demonstrated that barnacles incur differential survival and growth depending on precedence and position in an aggregation, and the same may be true for $H$. dianthus; early colonists have higher growth rates under field conditions than do aggregated worms (Toonen unpubl. data). This early advantage is likely to be maintained as an aggregation develops, because early settlers start to grow vertically from the substrate when encountering conspecifics, and the 'peak' of an aggregation is the optimal position for growth and survival in bidirectional flow, such as that in the tidal estuary in which these worms were collected (Pullen \& LaBarbera 1991). However, because fertilization decreases rapidly with distance among marine broadcast spawners (e.g. Levitan 1991, 1993, Levitan et al. 1991, 1992), founders have a much lower probability of successfully reproducing unless they subsequently attract gregarious settlement. Founders also have the additional hazard that they are selecting a habitat without obvious cues of suitability for long-term survival and growth (the substrate may be unoccupied for a good reason). Aggregators, on the other hand, respond specifically to water-soluble cues associated only with the bodies of live conspecific adults (Toonen \& Pawlik 1996), which is an obvious indicator of habitat suitability for post-settlement survival. Aggregating settlers may lose the advantage of precedence, and therefore suffer increased levels of intraspecific competition leading to decreased growth and reproductive rates, but the initial risk of settlement is greatly decreased. Furthermore, as aggregations grow, they become more susceptible to being torn from the substrate and destroyed by winter storms, and individual mortality rates are positively correlated with aggregation size (Toonen unpubl. data). Thus, female $H$. dianthus may be increasing their fitness by producing mostly larvae that respond to an obvious indicator of habitat suitability for post-settlement survival, but by also producing a few larvae that will become the nucleus of a new aggregation if they settle in a habitat that supports post-metamorphic survival and growth.

Such difference in larval settlement behavior is likely to lead to a parent-offspring conflict, because although parents may maximize persistence of their genotype by distributing their offspring among different habitats, founding and aggregating offspring are unlikely to experience similar risks of post-metamorphic survival given their settlement preferences. Those larvae destined to settle as founders may be a good risk when considering inclusive fitness from the viewpoint of the parents, because the benefits of both strategies (founding or aggregating) may be realized while costs associated with either strategy need not be paid in full. As an individual larva, however, the safest bet surely lies with habitats already proven suitable by the presence of living conspecific adults.

Similarly variable settlement patterns among sibling larvae have been described for the sea slugs Alderia modesta (Krug 1998a,b, Krug \& Zimmer 2000), and Haminaea callidegenita (Gibson 1995, Gibson \& Chia 1991, 1995). Gibson (1995) and Maldonado \& Young (1999) describe intra-clutch variability in the onset of larval competence and discuss possible adaptive significance of individual variability in settlement choice among larvae within a clutch of offspring. Krug \& Zimmer (Krug 1998a,b, Krug \& Zimmer 2000) go on to propose that the developmental polymorphism observed in the opisthobranch sea slug Alderia modesta results from individuals employing a bet-hedging strategy to maximize their fitness in variable marine environments. Together with our data, these studies provide growing evidence to suggest that individual variation among larval settlement preferences may be an important factor in determining the distribution and abundance of marine organisms with planktonic larvae. Behavioral polymorphisms in larval settlement are 
likely to be more common among benthic marine invertebrates with planktonic larvae than previously suspected, because in most studies of gregarious settlement there is appreciable settlement of larvae in control treatments, and variability in settlement preference among sibling larvae of gregarious species seems to be the norm rather than the exception. Raimondi \& Keough (1990) reviewed the literature on variability of larval settlement behavior and concluded: 'Whatever the mechanisms, variable behaviour exists in the larvae of most species; even under controlled laboratory conditions, most parents produce offspring that exhibit a range of behaviours in response to clear, simple stimuli...If both short and long range dispersal occurred there would effectively be a dispersal polymorphism.' They go on to summarize 3 examples-(1) settlement of the bryozoan Bugula neritina on basal versus distal portions of sea grass blades (Keough 1986, Keough \& Chernoff 1987); (2) gregarious and nongregarious settlement of the barnacle Chthamalus anisopoma (Raimondi 1988a,b, 1990); (3) variation in phototactic behavior exhibited by larvae of ascidians and bryozoans (Raimondi \& Keough 1990) — to support their contention that variability in larval settlement behavior is likely to be an adaptive response to either fluctuating selection pressures (possibly as a result of the temporally and spatially variable nature of benthic marine habitats), or negative genetic correlations with other traits.

Neither energetic nor environmental factors appear to account for the patterns of differential larval settlement among larvae of Hydroides dianthus documented here, and we can reject the desperate larva hypothesis as a general explanation for the initiation of aggregations in marine invertebrates with feeding planktonic larvae. Thus, a new hypothesis for variable settlement among larvae of gregarious species is needed to explain the initiation of aggregations in previously uncolonized habits. Variation among the offspring of individual dams in these experiments suggests that there may be a heritable genetic component to larval settlement choice, and we are currently examining the heritability of larval settlement preference in $H$. dianthus. Our research suggests that the proportion of founders spawned by an individual worm is a highly heritable trait (Toonen \& Pawlik 2001b), and we propose that some form of settlement polymorphism among individual larvae of the marine tube worm $H$. dianthus may account for the observed patterns of differential settlement presented herein.

Acknowledgements. We thank D. J. Mense, and especially A. A. Henrikson and S. G. 'Master-of-the-pump' Bullard, for both their assistance on this project and the helpful comments they provided on earlier versions of this manuscript. We also extend thanks to L. Borghesi, R. Grosberg, M. Hart, P. Marko, E. Pearson, D. Thiede, J. Stachowicz and the anonymous reviewers for their helpful comments and suggestions on the manuscript, and analyses. This research was supported by an Office of Naval Research grant (N00014-92-J-1144) and an NSF Presidential Young Investigator Award (OCE-9158065) to J.R.P., and a Natural Sciences \& Engineering Research Council of Canada (NSERC) post graduate scholarship and a Sir James Lougheed Award of Distinction to R.J.T. Contribution number 260 to UNCW's Center for Marine Science Research.

\section{LITERATURE CITED}

Beckmann M, Harder T, Qian PY (1999) Induction of larval attachment and metamorphosis in the serpulid polychaete Hydroides elegans by dissolved free amino acids: mode of action in laboratory bioassays. Mar Ecol Prog Ser 190: 167-178

Bridges TS, Heppell S (1996) Fitness consequences of maternal effects in Streblospio benedicti (Annelida: Polychaeta). Am Zool 36:132-146

Bryan PJ, Qian PY, Kreider JL, Chia FS (1997) Induction of larval settlement and metamorphosis by pharmacological and conspecific associated compounds in the serpulid polychaete Hydroides elegans. Mar Ecol Prog Ser 146: 81-90

Bryan PJ, Kreider JL, Qian PY (1998) Settlement of the serpulid polychaete Hydroides elegans (Haswell) on the arborescent bryozoan Bugula neritina (L.): evidence of a chemically mediated relationship. J Exp Mar Biol Ecol 220:171-190

Burke RD (1986) Phermones and the gregarious settlement of marine invertebrate larvae. Bull Mar Sci 39:323-331

Cahoon LB, Laws RA, Thomas CJ (1994) Viable diatoms and chlorophyll alpha in continental slope sediments on Cape Hatteras, North Carolina. Deep-Sea Res Part II Top Stud Oceanogr 41:767-782

Cahoon LB, Hartwell RS, King W, Striffler H (1998) Macroalgal biomass and species composition as indicators of water quality in two North Carolina tidal creeks. J Elisha Mitchell Sci Soc 114:165-172

Cole HA, Knight-Jones EW (1949) The setting behaviour of larvae of the European oyster Ostrea edulis L. and its influence on methods of cultivation and spat collection. Minist Agric Fish Food GB Ser II 17:1-39

Davis MA (1980) Variation in flight duration among individual Tetraopes beetles: implications for studies of insect flight. J Insect Physiol 26:403-406

de Jong-Westman M, Qian PY, March BE, Carefoot TH (1995) Artificial diets in sea urchin culture: effects of dietary protein level and other additives on egg quality, larval morphometrics, and larval survival in the green sea urchin, Strongylocentrotus droebachiensis. Can J Zool 73: 2080-2090

Dean TA, Hurd LE (1980) Development in an estuarine fouling community: the influence of early colonists on later arrivals. Oecologia (Berl) 46:295 - 301

DeSante D (1983) Annual variability in the abundance of migrant landbirds on Southeast Farallon Island, California. Auk 100:826-852

Dingle H (1980) The ecology and evolution of migration. In: Gauthreaux JSA (ed) Animal migration, orientation, and navigation. Academic Press, New York, p 1-101

Dingle H (1996) Migration: the biology of life on the move. Oxford University Press, New York, NY 
Eckert GL (1995) A novel feeding strategy of the tropical sand dollar, Encope michelini (Agassiz): adaptation to food limitation and an evolutionary link between planktotrophy and lecithotrophy. J Exp Mar Biol Ecol 187:103-128

Eyster LS, Pechenik JA (1987) Attachment of Mytilus edulis L. larvae on algal and byssal filaments is enhanced by water agitation. J Exp Mar Biol Ecol 114:99-110

Gaines SD, Bertness M (1993) The dynamics of juvenile dispersal: why field ecologists must integrate. Ecology 74:2430-2435

Gibson G (1995) Why be choosy? Temporal changes in larval sensitivity to several naturally-occurring metamorphic inducers in the opisthobranch Haminaea callidegenita. J Exp Mar Biol Ecol 194:9-24

Gibson GD, Chia FS (1991) Contrasting reproductive modes in two sympatric species of Haminaea (Opisthobranchia: Cephalaspidea). J Mollusc Stud 57:49-60

Gibson GD, Chia FS (1995) Developmental variability in the poecilogonous opisthobranch Haminaea callidegenita: Life-history traits and effects of environmental parameters. Mar Ecol Prog Ser 121:139-155

Gosselin LA, Qian PY (1997) Can bacterivory alone sustain larval development in the polychaete Hydroides elegans and the barnacle Balanus amphitrite? Mar Ecol Prog Ser 161:93-101

Gotelli NJ (1987) Spatial and temporal patterns of reproduction, larval settlement, and recruitment of the compound ascidian Aplidium stellatum. Mar Biol 94:45-51

Hadfield MG, Unabia CC, Smith CM, Michael TM (1994) Settlement preferences of the ubiquitous fouler Hydroides elegans. In: Thompson MF, Nagabushanam SR, Fingerman $M$ (eds) Recent developments in biofouling control: Indo-United States Conference, Bangalore, India, July 12-16, 1992. A. A. Balkema, Rotterdam, Netherlands and Brookfield, Vermont, p 65-74

Harder T, Qian P-Y (1999) Induction of larval attachment and metamorphosis in the serpulid polychaete Hydroides elegans by dissolved free amino acids: isolation and identification. Mar Ecol Prog Ser 179:259-271

Helfman GS, Facey DE, Hales LS, Boyeman EL (1987) Reproductive ecology of the American eel. Am Fish Soc Symp 1: $42-56$

Hubertz ED, Cahoon LB (1999) Short-term variability of water quality parameters in two shallow estuaries of North Carolina. Estuaries 22:814-823

Jaeckle WB (1994) Rates of energy consumption and acquisition by lecithotrophic larvae of Bugula neritina (Bryozoa: Cheilostomata). Mar Biol 119:517-523

Jaeckle WB (1995) Variation in size, energy content, and biochemical composition of invertebrate eggs: correlates to the mode of larval development. In: McEdward L (ed) Ecology of marine invertebrate larvae. CRC Press, Inc., Boca Raton, FL

Keough MJ (1986) The distribution of a bryozoan, Bugula neritina, on seagrass, Thalassia testudinus, blades: settlement growth and mortality. Ecology 67:846-857

Keough MJ, Chernoff H (1987) Dispersal and population variation in the bryozoan Bugula neritina. Ecology 68:199-210

Ketterson ED, Nolan VJ (1983) The evolution of differential bird migration. In: Johnston RF (ed) Current ornithology. Plenum Press, New York, p 357-402

Knight-Jones EW (1951) Gregariousness and some other aspects of the setting behaviour of Spirorbis. J Mar Biol Assoc UK 30:201-222

Knight-Jones EW (1953) Laboratory experiments on gregariousness during setting in Balanus balanoides and other barnacles. J Exp Biol 30:584-599
Krug PJ (1998a) Chemical and larval ecology of opisthobranch molluscs: variable development modes and settlement requirements for larvae of Alderia modesta. PhD thesis, University of California, San Diego

Krug PJ (1998b) Poecilogony in an estuarine opisthobranch: planktotrophy, lecithotrophy, and mixed clutches in a population of the ascoglossan Alderia modesta. Mar Biol 132: 483- 494

Krug PJ, Zimmer RK (2000) Developmental dimorphism and expression of chemosensory-mediated behavior: habitat selection by a specialist marine herbivore. J Exp Biol 203: $1741-1754$

Leggett WC (1984) Fish migrations in coastal and estuarine environments: a call for new approaches to the study of an old problem. In: McCleave JD, Arnold GP, Dodson JJ, Neill WH (eds) Mechanisms of migration in fishes. Plenum Press, New York, p 159-178

Leggett WC (1985) The role of migrations in the life history evolution of fish. In: Rankin MA (ed) Migration: mechanisms and adaptive significance. Marine science Institute, University of Texas at Austin, Port Aransas, TX, p 277-295

Levin LA, Bridges TS (1994) Control and consequences of alternative developmental modes in a poecilogenous polychaete. Am Zool 34:323-332

Levin LA, Bridges TS (1995) Pattern and diversity in reproduction and development. In: McEdward LR (ed) Ecology of marine invertebrate larvae. CRC Press, Inc., Boca Raton, FL, p 1-48

Levitan DR (1991) Influence of body size and population density on fertilization success and reproductive output in a freespawning invertebrate. Biol Bull (Woods Hole) 181:261-268

Levitan DR (1993) The importance of sperm limitation to the evolution of egg size in marine invertebrates. Am Nat 141:517-536

Levitan DR, Sewell MA, Chia FS (1991) Kinetics of fertilization in the sea urchin Strongylocentrotus franciscanus: interaction of gamete dilution, age and contact time. Biol Bull 181:371-378

Levitan DR, Sewell MA, Chia FS (1992) How distribution and abundance influence fertilization success in the sea urchin Strongylocentrotus franciscanus. Ecology 73:248-254

Maldonado M, Young CM (1999) Effects of the duration of larval life on postlarval stages of the demosponge Sigmadocia caerulea. J Exp Mar Biol Ecol 232:9-21

Mallin MA, Cahoon LB, McIver MR, Parsons DC, Shank GC (1999) Alternation of factors limiting phytoplankton production in the Cape Fear River Estuary. Estuaries 22: 825-836

McEdward LR (1996) Experimental manipulation of parental investment in echinoid echinoderms. Am Zool 36:169-179

McEdward LR, Chia FS (1991) Size and energy content of eggs from echinoderms with pelagic lecithotrophic development. J Exp Mar Biol Ecol 147:95-102

McFarlane GA, Beamish RJ (1986) A tag suitable for assessing long-term movements of spiny dogfish and preliminary results from the use of this tag. N Am J Fish Manag 6:69- 76

McShea WJ (1992) Alternative approaches to the study of small mammal dispersal: insights from radiotelemetry. In: Stenseth NC, Lidicker WZJ (eds) Animal dispersal: small mammals as a model. Chapman \& Hall, London, p 319-332

Menge BA (1991) Relative importance of recruitment and other causes of variation in rock intertidal community structure. J Exp Mar Biol Ecol 146:69-100

Moran AL (1999) Size and performance of juvenile marine invertebrates: potential contrasts between intertidal and subtidal benthic habitats. Am Zool 39:304-312 
Pawlik JR (1992) Chemical ecology of the settlement of benthic marine invertebrates. Oceanogr Mar Biol Annu Rev 30:273-335

Pawlik JR, Mense DJ (1994) Larval transport, food limitation, ontogenetic plasticity, and the recruitment of sabellariid polychaetes. In: Wilson WHJ, Stricker SA, Shinn GL (eds) Reproduction and development of marine invertebrates. Symposium, Friday Harbor, Washington, USA, June 9-11, 1992. Johns Hopkins University Press, Baltimore, MD, p 275-286

Pechenik JA, Estrella MS, Hammer K (1996a) Food limitation stimulates metamorphosis of competent larvae and alters postmetamorphic growth rate in the marine prosobranch gastropod Crepidula fornicata. Mar Biol 127:267-275

Pechenik JA, Hammer K, Weise C (1996b) The effect of starvation on acquisition of competence and post-metamorphic performance in the marine prosobranch gastropod Crepidula fornicata (L.). J Exp Mar Biol Ecol 199:137-152

Pepin P, Meyer RA (1991) Significance of egg and larval size to recruitment variability of temperate marine fish. Can J Fish Aquat Sci 48:1820-1828

Pullen J, LaBarbera M (1991) Modes of feeding in aggregations of barnacles and the shape of aggregations. Biol Bull 181:442-452

Qian PY (1994) Effect of food quantity on growth and reproductive characteristics of Capitella sp. (Annelida: Polychaeta). Invertebr Reprod Dev 26:175-185

Qian PY, McEdward LR, Chia FS (1990) Effects of delayed settlement on survival, growth, and reproduction in the spionid polychaete, Polydora ligni. Invertebr Reprod Dev 18:147-152

Quinn TP (1984) Homing and straying in Pacific salmon. In: McCleave JD, Arnold GP, Dodson JJ, Neill WH (eds) Mechanisms of migration in fishes. Plenum Press, New York, p 357-362

Quinn TP (1985) Homing and evolution of sockeye salmon (Oncorhychus nerka). In: Rankin MA (ed) Migration: mechanisms and adaptive significance. Marine Science Institute, the University of Texas at Austin, Port Aransas, Tx p 351-366

Quinn TP, Brodeur RD (1991) Intra-specific variations in the movement patterns of marine animals. Am Zool 31: 231-242

Raimondi PT (1988a) Rock type affects settlement, recruitment, and zonation of the barnacle Chthamalus anisopoma Pilsbry. J Exp Mar Biol Ecol 123:253-268

Raimondi PT (1988b) Settlement cues and determination of the vertical limit of an intertidal barnacle. Ecology 69:400-407

Raimondi PT (1990) Settlement behavior of Chthamalus anisopoma larvae largely determines the adult distribution. Oecologia (Berl) 85:349-360

Raimondi PT, Keough MJ (1990) Behavioral variability in marine larvae. Aust J Ecol 15:427-438

Editorial responsibility: Otto Kinne (Editor),

Oldendorf/Luhe, Germany
Raimondi PT, Martin JE (1991) Evidence that mating group size affects allocation of reproductive resources in a simultaneous hermaphrodite. Am Nat 138:1206-1217

Scheltema RS, Williams IP, Shaw MA, Loudon C (1981) Gregarious settlement by the larvae of Hydroides dianthus (Polychaeta: Serpulidae). Mar Ecol Prog Ser 5: $69-74$

Sinervo B, McEdward LR (1988) Developmental consequences of an evolutionary change in egg size: an experimental test. Evolution 42:885-899

Snedecor GW, Cochran WG (1989) Statistical methods, 8th edn. Iowa State University Press, Ames, Iowa

Sokal RR, Rohlf FJ (1981) Biometry. The principles and practice of statistics in biological research, 2nd edn. W. H. Freeman \& Company, New York, NY

Sutherland JP, Karlson RH (1977) Development and stability of the fouling community at Beaufort North Carolina. Ecol Monogr 47:425 - 446

Tamburri MN, Zimmerfaust RK, Tamplin ML (1992) Natural sources and properties of chemical inducers mediating settlement of oyster larvae-a re-examination. Biol Bull 183:327-338

Thorson G (1964) Light as an ecological factor in the dispersal and settlement of larvae of marine bottom invertebrates. Ophelia 1:167-208

Toonen RJ (1993) Environmental and heritable components of settlement behavior of Hydroides dianthus (Serpulidae: Polychaeta). University of North Carolina at Wilmington, Wilmington, NC

Toonen RJ, Pawlik JR (1994) Foundations of gregariousness. Nature (Lond) 370:511-512

Toonen RJ, Pawlik JR (1996) Settlement of the tube worm Hydroides dianthus (Polychaeta: Serpulidae): cues for gregarious settlement. Mar Biol 126:725-733

Toonen RJ, Pawlik JR (2001a) Settlement of the gregarious tube worm Hydroides dianthus (Polychaeta: Serpulidae). I. Gregarious and nongregarious settlement. Mar Ecol Prog Ser 224:103-114

Toonen RJ, Pawlik JR (2001b) Foundations of gregariousness: a dispersal polymorphism among the larvae of a marine invertebrate. Evolution (in press)

Unabia CRC, Hadfield MG (1999) Role of bacteria in larval settlement and metamorphosis of the polychaete Hydroides elegans. Mar Biol 133:55-64

Wilson DP (1953) The settlement of Ophelia bicornis Savigny larvae. J Mar Biol Assoc UK 32:209-233

Yvin JC, Chevolot J, Chevolot-Magueur AM, Cochard JC (1985) First isolation of jacaranone from an alga, Delesseria sanguinea. A metamorphosis inducer of Pecten larvae. J Nat Prod (Lloydia) 48:814-816

Zimmerfaust RK, Tamburri MN (1994) Chemical identity and ecological implications of a waterborne larval settlement cue. Limnol Oceanogr 39:1075-1087

Submitted: July 21, 2000, Accepted: January 15, 2001

Proofs received from author(s): November 23, 2001 